DOI https://doi.org/10.30525/978-9934-588-81-5-1.13

\title{
ЗАСТОСУВАННЯ МОВІНАЗИ У КОМПЛЕКСНОМУ ЛІКУВАННІ ЗАХВОРЮВАНЬ СКРОНЕВО-НИЖНЬОЩЕЛЕПНОГО СУГЛОБА
}

\author{
Воловар О. C. \\ доктор медичних наук,
}

професор кафедри хірургічної стоматології та щелепно-лищевої хірургї Національний медичний університет імені О. О. Богомольия

Крижанівська О. О.

асистент кафедри хірургічної стоматологї та щелепно-лищевої хірургії Національний медичний університет імені О. О. Богомольияя

Швидченко В. С. кандидат медичних наук, асистент кафедри хірургічної стоматології та щелепно-лищевої хірургії Національний медичний університет імені О. О. Богомольия м. Київ, Украӥна

Остеоартроз скронево-нижньощелепного суглоба (ОА СНЩС) дегенеративно-дистрофічне захворювання поліетіологічної природи, що супроводжується больовими відчуттями та звуками у суглобі, порушенням його функцій. Складність будови та біомеханіки СНЩС обумовлюють значні труднощі лікування, незважаючи на широкий спектр існуючих препаратів і методів. Для досягнення позитивних результатів лікування слід диференційовано та комплексно підбирати медикаментозну терапію для кожного клінічного випадку $[1,2]$.

При лікуванні ОА СНЩС враховують клінічну картину, стадію захворювання, біль. Своєчасність і повноцінність проведення лікувальних заходів важливі для сповільнення патологічного процесу. Лікування направлене на пригнічення активності запального процесу, запобігання деградації суглоба, відновлення його функції тощо $[2,3]$.

Останнім часом препарати системної ензимотерапії набули популярності завдяки своїй вираженій протизапальній, протинабряковій та знеболювальній дії [4]. Серратіопептидаза (Serratia E-15 протеаза), відома також як серралізин, сератіо-протеаза, серапептаза, являє собою протеолітичний фермент, виділений 3 непатогенної кишкової бактерії Serratia E15. Пероральна форма цього ферменту широко застосовується в різних галузях медицини, таких як хірургія, ортопедія, отоларингологія, гінекологія, стоматологія тощо. Обгрунтуванням 
такого широкого іiі використання є те, що іiі фібринолітична, протизапальна та протинабрякова активність в уражених тканинах перевищує таку у інших протеолітичних ферментів $[4,5]$.

У ділянці запалення серратіопептидаза блокує вивільнення больових амінів з уражених тканин, внаслідок чого зменшується вираженість больового синдрому. Вона зв'язується $3 \alpha_{2}$-макроглобуліном крові у співвідношенні 1:1, котрий маскує іiі антигенність, але зберігає ферментативну активність. Гідролізуючи брадикінін, гістамін та серотонін, серратіопептидаза знижує рівень медіаторів запалення та болю, зменшує розширення капілярів і контролює іх проникність. Окрім того, цей фермент блокує інгібітори плазміну, чим сприяє його фібринолітичній активності, та гідролізує фібрин, перешкоджаючи утворенню спайок, покращує мікроциркуляцію, завдяки чому підвищується біодоступність НПЗП, антибіотиків і деяких інших фармакологічних речовин $[6,7,8]$. Клінічно це проявляється фібринолітичним, протизапальним, протинабряковим та анальгетичними ефектами.

Мета роботи: оцінити ефективність застосування серратіопептидази у пацієнтів із дегенеративно-дистрофічними захворюваннями СНЩС із больовим синдромом.

Матеріали та методи: 36 пацієнтів (ч-11, ж-25) із захворюваннями СНЩС, середній вік $45,2 \pm 7,3$ років, у яких в анамнезі були відсутні порушення згортання крові, алергічні реакції на будь-які компоненти досліджуваних препаратів, тяжка супутня патологія внутрішніх органів. Пацієнти були розділені на 2 групи: основна - 18 осіб, порівняння - 18 осіб.

Обстеження хворих проводили за класичною методикою обстеження пацієнтів із захворюваннями СНЩС: до лікування, на 7, 21, 30 добу після призначеного курсу медикаментозної терапії. Вираженість больового синдрому оцінювали за шкалою Verbal Descriptor Scale (VDS), згідно якої: 0 балів - немає болю, 2 бали - слабкий біль, 4 бали - помірний біль, 6 балів - сильний біль, 8 балів - дуже сильний біль, 10 балів - нестерпний біль [8].

Пацієнти групи порівняння приймали НПЗП 14 днів (мелоксикам у формі ОДТ - 15 мг/добу), хондропротектори протягом 2-3 місяців (хондроітину сульфат і глікозаміну гідрохлорид - по 1000 мг/добу), комбіновані препарати кальцію та вітаміну D3 протягом 2-3 місяців (500 мг - 2 таб/добу). Пацієнти основної групи додатково приймали серратіопептидазу 10 мг по 1 таблетці 3 рази/добу протягом 20 днів при вираженості больового синдрому до 6 балів і 30 днів при наявності болю більше 8 балів. Пацієнтів спостерігали на 7, 21, 30 день лікування. 
Результати: Більшість хворих - 30 (83,3 \%) скаржилися на біль у СНЩС. Помірний тупий ниючий біль у СНЩС у стані спокою був у $19(52,8 \%)$ пацієнтів, середне значення якого за VDS становило $3,5 \pm 1,1$ балів. У цих осіб під час жування твердої їжі чи активних рухах нижньої щелепи біль посилювався та складав 6,1 $\pm 1,3$ бали. У 12 (33,3\%) осіб були скарги на сильний біль $(5,9 \pm 1,0$ балів) у СНЩС лише при відкриванні рота та жуванні твердої їжі, в стані спокою біль не виникав.

У 20 (55,6\%) пацієнтів відмічалася ранкова скутість у ділянці ураженого суглоба від 15 до 20 хвилин, що поступово зменшувалася i зникала. При відкриванні рота 100 \% пацієнтів відмічали появу крепітації чи хрускоту у суглобі. При об'єктивному обстеженні у хворих виявлено обмеження рухів нижньої щелепи, відкривання рота складало 3,25 $\pm 0,86$ см. Діагностовано зміщення щелепи при відкриванні рота в бік ураженого СНЩС, хрускіт чи крепітацію в суглобі.

Під час опитування у $100 \%$ пацієнтів обох груп через 7 днів лікування 3'ясовано, що біль у СНЩС зменшився, майже не турбував в стані спокою $-2,1 \pm 1,1$ бали. Під час жування біль зберігався, однак став менш інтенсивним $(4,3 \pm 1,0$ бали): у $22(61,1 \%)$ осіб біль був помірним і 14 (38,9 \%) пацієнтів відмічали біль слабкий. У хворих обох груп під час повторних відвідувань відмітили збільшення відкривання рота до 4,0 $\pm 1,0$ см, покращення об'єму рухів нижньої щелепи, зменшився хрускіт і крепітація в суглобі.

На 21 день лікування з'ясовано, що біль у СНЩС у пацієнтів обох груп у стані спокою після закінчення прийому НПЗП був меншим, ніж до початку лікування та складав в основній групі $2,1 \pm 1,1$ балів, а в групі порівняння $3,5 \pm 1,1$ балів. Під час жування біль у пацієнтів основної групи були також меншими $(2,2 \pm 0,8$ бали), ніж у пацієнтів групи порівняння $(3,8 \pm 0,9$ бали).

Пацієнти основної групи під час повторних відвідувань через 1 місяць спостереження мали достовірно кращі показники зменшення болю як в стані спокою так і під час жування: відповідно $0,6 \pm 0,4$ та $2,1 \pm 1,1$ бали (p <0,05) - стан спокою; $1,6 \pm 1,1$ та $3,3 \pm 1,0$ бали $(\mathrm{p}<0,05)$ - під час активних рухів нижньої щелепи. Така ж закономірність відмічалася і в покращенні об'єму рухів нижньої щелепи та відкриванні рота в пацієнтів основної групи, порівняно з групою порівняння, відповідно 4,3 $\pm 0,9$ см та 3,9 $\pm 0,7$ см $(\mathrm{p}<0,05)$.

Висновки:

1. Застосування серратіопептидази в комплексному лікуванні пацієнтів із захворюваннями СНЩС із вираженим больовим синдромом зменшує біль у суглобі як в стані спокою, так і при активних рухах нижньої щелепи, дозволяє покращити об'єм рухів у СНЩС, ступінь 
відкривання рота до 4,4 $\pm 1,0$ см, порівняно 3 групою порівняння $(\mathrm{p}<0,05)$.

2. Препарат серратіопептидази добре переносився пацієнтами, не було скарг з боку травної, сечовидільної систем, алергічних реакцій. Виявлено достовірне поступове зниження болю, покращення відкривання рота, зменшення хрускоту та крепітації в СНЩС у обох групах протягом усього часу дослідження ( $<<0,05)$.

3. Серратіопептидаза може використовуватися у хворих із захворюваннями СНЩС для усунення болю, зменшення набряку в периартикулярних тканинах, потенціювання дії НПЗП, хондропротекторів при лікуванні захворювань суглоба. При вираженості больового синдрому $\leq 6$ балів за шкалою VDS рекомендований курс лікування 21 день, при больовому синдромі $\geq 6$ балів -30 днів.

\section{Література:}

1. Воловар О.С. Діагностика та лікування захворювань скроневонижньощелепного суглоба на фоні соматичних захворювань: автореф. дис. ... д-ра мед. наук: спец. 14.01.22. Київ, 2013. 40 с.

2. Murphy M.K., MacBarb R.F., Wong M.E., Athanasiou K.A. Temporomandibular Joint Disorders: A Review of Etiology, Clinical Management, and Tissue Engineering Strategies. The International journal of oral \& maxillofacial implants. 2013. Vol. 28(6). P. e393-e414.

3. Wang X.D., Kou X.X., Mao J.J. et al. Sustained inflammation induces degeneration of the temporomandibular joint. Journal of Dental Research. 2012. Vol. 91. № 5. P.499-505.

4. Tiwari M. The role of serratiopeptidase in the resolution of inflammation. Asian journal of pharmaceutical sciences. 2017. Vol. 12. P. 209-215.

5. Поворознюк В.В., Орлик Т.В., Бистрицька М.А. Застосування препаратів Мовекс $\AA$ і Мовіназа ${ }^{\circledR}$ в комплексному лікуванні хворих старших вікових груп з остеоартрозом великих суглобів. Здоров'я України. 2013. № 22(323). С. 16-18.

6. Garg R., Aslam S., Garg A., Walia R. A prospective comparative study of serratiopeptidase and aceclofenac in upper and lower limb soft tissue trauma cases. Intern. J. Pharmacol. Pharmaceut. Technol. 2012. Vol. 1(2). P. 2277-3436.

7. Воловар О.С., Крижанівська О.О. Серратіопептидаза в комплексному лікуванні захворювань скронево-нижньощелепного суглоба. Вісник стоматологї. 2019. № 4(109). С. 50-56. 